\title{
Effect of Financial Knowledge and Financial Experience on Investment Planning Behavior with Self Control as a Moderating Variable
}

\author{
Ida Subaida ${ }^{1}$, Fiqih Nur Hakiki ${ }^{2}$ \\ \{ida_subaida@unars.ac.id ${ }^{1}$, fiqihnurhakiki@gmail.com² ${ }^{2}$, \\ Abdurachman Saleh Situbondo University
}

\begin{abstract}
The economy of the people of Situbondo district which is still lacking makes Situbondo district as one of the three districts in East Java Province which is classified as a disadvantaged area. One thing that can cause a lack of community economy is the financial investment planning behavior in Situbondo people is also less than optimal. The purpose of this study was to determine and analyze the effect of financial knowledge and financial experience on investment planning behavior that is moderated by self control. This research was conducted on families in Tokelan Village, Panji District, Situbondo Regency. Data analysis methods in this research are outer and inner testing models using PLS Warp. The results of the study are that financial knowledge and financial experience influences investment planning behavior and self control is not a moderating variable of the relationship between financial knowledge and financial experience on investment planning behavior.
\end{abstract}

Keywords: Financial Knowledge, Financial Experience, Investment Planning Behavior, Self Control.

\section{Introduction}

Situbondo Regency, East Java is one of the least developed regions in Indonesia in 20152019. One of the criteria for determining underdeveloped areas is the economy of the community. The economy of the people of Situbondo district which is still lacking makes Situbondo district as one of the three districts in East Java Province which is classified as a disadvantaged area. One thing that can cause a lack of community economy is the investment planning behavior in Situbondo people is also less than optimal.

Investment planning behavior is an activity to allocate funds at the moment in the hope of earning benefits in the future [9]. Investment planning depends on several factors which may differ between individuals. Some people make investment decisions with temporary considerations and some others make complex considerations [4]. Some things that can influence investment planning behavior are financial knowledge and financial experience.

Financial knowledge can lead to more profitable investment activities [5]. [9] also conducted research on the relationship of factors that influence investment planning and stated that financial knowledge has a positive effect on investment planning. Different results are stated in [3], which is that financial knowledge has no effect on investment decisions.

In addition to financial knowledge, financial experience can also influence the investment planning behavior. Financial experience has a positive effect on investment planning behavior. A person will learn from past experience in investment [4]. Financial experience has a positive effect on family financial behavior [8]. 
The relationship of financial knowledge and financial experience to investment planning behavior related to self control. Research [9] says that self control moderates the relationship of financial knowledge and financial experience to investment planning behavior. Self control weakens the relationship of financial knowledge and financial experience to the behavior of investment planning.

The motivation for this research is to examine the effect of financial knowledge and financial experience on investment planning behavior with self control as a moderating variable. The second motivation is because there are inconsistencies from the results of previous studies. [5] and [9] state that financial knowledge has a positive effect on investment planning, but [3] revealed that financial knowledge has no effect on investment decisions.

This research is a development from previous research. The difference between this study and previous research on the population distribution of the study is the family in the village of Tokelan, District Panji, Situbondo Regency. Research on investment planning behavior has never been done in Tokelan village, Panji District, Situbondo Regency. The population selection is adjusted to the condition that Situbondo Regency is one of the disadvantaged areas in Indonesia in 2015-2019. The purpose of this study was to determine and analyze the effect of financial knowledge and financial experience on investment planning behavior that is moderated by self control.

\section{Literature Review}

\subsection{The effect of financial knowledge on investment planning behavior}

[2] conducted research on financial knowledge and investment decisions on 290 investors in the United Arab Emirates. The results of the study report that financial knowledge has a negative effect on investment decisions. Investors who have good financial knowledge will reduce their dependence on other factors in investing. This will result in investment planning will decline along with the better financial knowledge possessed by investors. An increase in the level of knowledge about financial information and an increase in analyzing that information can result in an increase in avoiding risky investments and getting high opportunities for returns by managing investments efficiently. Owned financial knowledge can also help overcome risks in investments made [4].

Research on financial knowledge and investment planning behavior was also carried out by [5]. This research was conducted on employees. The results of the study stated that financial knowledge helps in investment activities. Rich employees with better financial knowledge have proven benefits from higher investment than employees who lack financial knowledge. According to [9] revealed that there is an influence of financial knowledge on investment planning. One reason someone does not do a good investment planning is due to lack of financial knowledge possessed by that person. According to [1] individuals use mental skills in understanding management and problem solving in decision making, as well as in financial investment decisions. The better the financial knowledge of individuals, the better the financial behavior will be as in investment decision making.

Hypothesis 1: financial knowledge has a positive effect on investment planning behavior.

The effect of financial experience on investment planning behavior

High investment experience will direct investors to high risk investments. With this experience, investors can have investments with returns that match those high risks. Wise 
investors will learn from past experience to overcome risky conditions and handle them properly [4].

[9] also conducted research related to the relationship of financial experience to investment planning behavior. The results of the study stated that financial experience influences investment planning. Experience can improve investment decisions and planning. [8] also revealed that financial experience has a positive effect on financial behavior.

Financial experience can be used as learning for someone in financial management and in future decision making. Experience can be obtained from personal experience or other people who have made investments, so as to improve management, decision making and investment planning [7].

Hypothesis 2: financial experience has a positive effect on investment planning behavior.

\subsection{The influence of financial knowledge and financial experience on investment planning behavior that is moderated by self control}

[7] says that self control moderates the relationship of financial knowledge and financial experience to the behavior of investment planning. Self control weakens the relationship of financial knowledge and financial experience to the behavior of investment planning.

Hypothesis 3: self control weakens the relationship of financial knowledge and financial experience to investment planning behavior

\section{Method}

The population in this study were families in Tokelan Village, Panji District, Situbondo Regency. The sample in this study used purposive sampling, with the following criteria: a. Family availability to participate in this study. b. Families who have basic safety regarding this research variable. The sample of this study were 35 samples.

The independent variables of this study are financial knowledge and financial experience. Financial knowledge is the basic knowledge of everyone to avoid financial problems [9]. Financial experience is learning in managing finances so that they can make financial decisions well [9]. Financial knowledge and financial experience in this study were measured by questionnaire items that have been used by [7]. The dependent variable of this study is the behavior of investment planning. Investment planning is the activity of allocating funds in the hope of future benefits [9]. Investment planning behavior in this study was measured by questionnaire items that have been used by [7].

The moderating variable of this study is self control. Self control is a strategy used in preventing waste in financial allocations [7]. Investment self control in this study was measured by questionnaire items used by [7]. Data obtained from the data collection process were analyzed using PLS Warp. Data analysis methods in this research are descriptive statistics and outer and inner testing models. This test includes testing the construct validity (convergent and discriminant) and construct reliability testing (Cronbach's alpha and composite reliability). The rule of thum used for testing convergent validity is cummunality and average vaiance extracted (AVE) $>0.5$ with redundancy approaching 1 . The rule of thumb for discriminant validity is through cross loading $>0.7$ in one variable. For reliability testing, cronbach's alpha $>0.6$ and composite reliability value must be $>0.7$ (Hartono and Abdillah, 2009: 74). The structural model in PLS is evaluated by using R2 for the dependent construct, the value of the inter-construct significance test in the structural model [6]. 


\section{Result And Discussion}

\subsection{Outer Model Testing}

Testing the relationship between latent variables with the indicators obtain the results of the coefficient or loading factor of each indicator has met the criteria so that no indicators are removed from the research model. The number of indicators for the Financial Knowledge variable is 5 indicators, the indicator for the Financial Experience variable is 3 indicators, the number of indicators for the Investment Planning Behavior variable is 5 indicators, and the number of indicators for the Self Control variable is 4 indicators.

\begin{tabular}{ccccc}
\multicolumn{6}{c}{ Table 1. Outer Model Test Results } \\
\hline Explanation & $\begin{array}{c}\text { Financial } \\
\text { Knowledge }\end{array}$ & $\begin{array}{c}\text { Financial } \\
\text { Experience }\end{array}$ & $\begin{array}{c}\text { Investment Planning } \\
\text { Behavior }\end{array}$ & $\begin{array}{c}\text { Self } \\
\text { Control }\end{array}$ \\
\hline R-squared & & & 0,700 & \\
Composite reliab. & 0,951 & 0,871 & 0,985 & 0,954 \\
Cronbach's alpha & 0,935 & 0,770 & 0,981 & 0,936 \\
Avg. Var. Extrac & 0,795 & 0,698 & 0,928 & 0,840 \\
Full Collin. VIF & 3,998 & 4,884 & 4,885 & 2,123 \\
Q-Squared & & & 0,721 & \\
\hline
\end{tabular}

The coefficient of determination measured using R-Square shows a result of 0.700 for investment planning behavior which means that the variance in investment planning behavior is explained by $70 \%$ by the variance of Financial Knowledge and Financial Experience. For testing the predictive validity, the Q-squared value indicates a value above zero, is, 0.721 . These results indicate the research model has good predictive validity. The research model also meets the criteria of convergent validity as indicated by Average Variance Extracted (AVE) values above 0.50 in the amount of $0.795,0.689,0,928$, and 0,840 . While for reliability testing, the composite reliability value is $0.951,0,871,0,985$, and 0.954 and Cronbach's alpha of $0.935,0.770,0,981$, and 0,936 . The value is above 7 so that the reliability criteria are met in this study. Inner Model Testing The outer model test results in the previous discussion showed good validity, reliability, and VIF criteria so that the research model could be continued in the inner model testing. Inner model research is conducted to determine the effect of research variables and the influence of moderation variables. The results of testing the inner model in this study are shown in Figure 1.

The first test is testing the effect of Financial Knowledge on Investment Planning Behavior. The test results show that the influence of Financial Knowledge on Investment Planning Behavior is significant, namely the value of $P=0.03$. This value is below 0.05 so that the first test results show that Financial Knowledge influences Behavior in Investment Planning.

The second test is testing the effect of Financial Experience on Investment Planning Behavior. The results obtained are the effect of Financial Experience on Investment Planning Behavior significantly with a $\mathrm{P}$ value $<0.01$. These results indicate a significance level of less than 0.05 which means that there is an influence of Financial Experience on Investment Planning Behavior.

The third inner testing model is testing the effect of Financial Knowledge and Financial Experience on Investment Planning Behavior that is moderated by Self Control. The test results show that the level of siginification is greater than $0.05,0.50$ for Financial Knowledge and 0.17 for Financial Experience. These results indicate that Self Control is not a moderating 
variable of the relationship between Financial Knowledge and Financial Experience on Investment Planning Behavior.

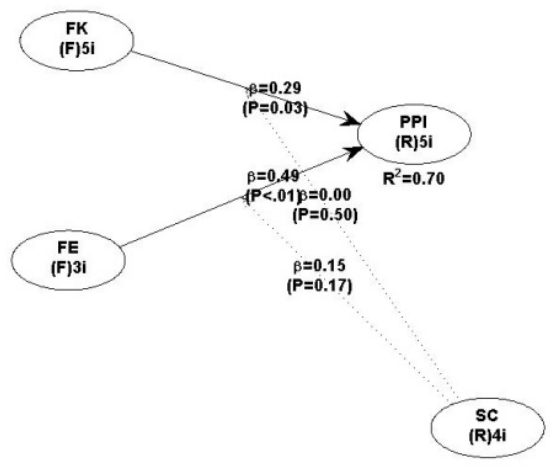

Fig.1. Inner Model Test Result

The first result of the study is that financial knowledge influences investment planning behavior. These results support research conducted by [4], [5], and [9]. The study revealed that financial knowledge influences investment planning behavior. Financial knowledge that is owned by the family can be used as a basis for making decisions on investment planning that will be done. Families with high financial knowledge will be able to choose investments that can provide high returns and avoid risky investments. Financial knowledge that is owned by the family can also be used as a solution in overcoming risks in investment activities.

Financial Knowledge can be in the form of basic knowledge about personal finance, money management knowledge, credit and debt management knowledge, savings and investment knowledge, and risk management knowledge. Financial knowledge influences investment planning behavior which can be in the form of ability to calculate security and risk, ability to predict risk factor components, ability to forecast investment income, understanding of investment growth, and ability to analyze liquidity.

The second result of this study is that there is an influence of financial experience on investment planning behavior. The results of this study support the research of [9], which is that financial experience influences investment planning. Experience can improve investment decisions and planning. The results of the study also support the research of [7] who reported that financial experience had an effect on investment planning behavior.

Families with good financial experience will tend to do investment planning well too. Their financial experience can be used as learning for families in investing in the future. Financial experience can also improve management, decision making, and investment planning. Financial experience can be in the form of family planning, income and expenditure planning, having done financial statement analysis, and ever making financial reports.

The final results of this study are that self control is not a moderating variable of the relationship between financial knowledge and financial experience on investment planning behavior. These results do not support research [7]) which reports that self control moderates the relationship of financial knowledge and financial experience to investment planning behavior. Self control weakens the relationship of financial knowledge and financial experience to the behavior of investment planning.

Self control which can be in the form of an attitude of family initiative to save unexpected expenses, intention to make savings, feeling uncomfortable without financial planning, and feeling uncomfortable doing unnecessary expenses. Some of the self-control attitudes of the 
family in Tokelan Village, Panji Subdistrict, Situbondo Regency, were not proven to moderate the relationship between financial knowledge and financial experience on investment planning behavior.

\section{Conclusion}

The results of the study are that Financial Knowledge influences Behavior of Investment Planning, Financial Experience influences Behavior of Investment Planning, and Self Control is not a moderating variable of the relationship between Financial Knowledge and Financial Experience on Behavior of Investment Planning. The results of the study have implications that can be input into family decision-making related to investment planning behavior that is by paying attention to Financial Knowledge and Financial Experience. Families need to maximize the benefits of investment activities carried out and avoid risky investments. Families also need to pay attention to Financial Knowledge and Financial Experience to overcome the risks posed by investment activities undertaken. The limitation of this study is that it examines families within the village that can cause a small sample size. Future studies can expand the research sample at the district or city level.

\section{Acknowledgements}

Acknowledgments. Researchers would like to thank the Ministry of Research and Technology / National Research and Innovation Agency for funding this research.

\section{References}

[1] Aminatuzzahra.: Persepsi Pengaruh Pengetahuan Keuangan, Sikap Keuangan, Sosial Demografi terhadap Perilaku Keuangan dalam Pengambilan Keputusan Investasi Individu. Jurnal Bisnis Strategi, 23 (2), 70-96 (2014)

[2] Al-Tamini, H.A.H., \& Anood, A.B.K.: Financial Literacy and Investment Decisions of UAE Investors. The Journal of Risk Finance, 10 (5), 500-516. (2009)

[3] Arianti, B.F.: The Influence of Financial Literacy, Financial Behavior and Income on Investment Decision. Economics \& Accounting Journal, 1 (1), 1-10. (2018)

[4] Awais, M., Laber, M.F., Rasheed. N., \& Khurseed, A.: Impact of Financial Literacy and Investment Experience on Risk Tolerance and Investment Decisions: Empirical Evidence from Pakistan. International Journal of Economics and Finance Issues, 6 (1), 73-79. (2016)

[5] Clark, R.L., Lusardi, A., \& Mitchell, O.S.: Financial Knowledge and 401 (k) Investment Performance. NBER Working Paper, 20137, 1-27. (2014)

[6] Hartono, M.J dan Abdillah W.: Konsep dan aplikasi partial least square (PLS) untuk penelitian empiris. BPFE:Yogyakarta. (2009)

[7] Pritazahara, R. \& Sriwidodo, U.: Pengaruh Pengetahuan Keuangan dan Pengalaman Keuangan terhadap Perilaku Perencanaan Investasi dengan Self Control sebagai Variabel Moderating. Jurnal Ekonomi dan Kewirausahaan, 15 (1), 28-37. (2015)

[8] Purwidianti, W., Mudjiyanti, R.: Analisis Pengaruh Pengalaman Keuangan dan Tingkat Pendapatan terhadap Perilaku Keuangan Keluarga di Kecamatan Puwekerto Timur. Jurnal Manajemen dan Bisnis BENEFIT, 1 (2) 141-148. (2016) 
[9] Sriwidodo, U. \& Sumaryanto.: Analisis Faktor yang Berpengaruh terhadap Perencanaan Investasi. Research Fair Unisri, 1 (1), 91-97. (2017) 